J. Product. \& Dev., 24(3): 623-646 (2019)

\title{
EFFECT OF DIFFERENT DIETARY LEVELS OF COENZYME Q10 SUPPLEMENTATION ON THE PERFORMANCE OF SINAI COCKS FED LOW ENERGY DIET
}

\author{
M.M. Beshara*, H. N. Fahim, Y.S. Rizk, H.M.M. Azouzand A.A. Habeib
}

Anim. Prod. Res. Instit., Agric. Res. Center, Minis. of Agric. Dokki, Giza.

*Corresponding author: Malak Mansour; E-mail: malakman88@yahoo.com

\begin{abstract}
:
The aim of the current study was to investigate the influence of different dietary levels of Coenzyme Q10 (CoQ10) supplementation in local Sinai cock's diet containing low metabolizable energy on the viability, hematology traits, reproductive and economic performance during the period from 40-56 weeks of age. Fifty four of Sinai cocks were weighed and divided into six treatment groups of three replicates in each and housed in individually cages The experimental diets containing two levels of energy (2940 and $2800 \mathrm{Kcal} / \mathrm{Kg}$ diet) and three levels of Coenzyme Q10 (CoQ10) ( 0, $7.5 \mathrm{mg}$ CoQ10 synthetic (s) or natural (n) in $2 \times 3$ factorial arrangement.
\end{abstract}

Resulted obtained indicated that body weight of cocks fed diet contained low $M E+7.5 \mathrm{mg} C o Q 10 \mathrm{~s} / \mathrm{kg}$ diet was significantly $(P \leq 0.05)$ decreased as compared to those fed diets containing low ME without CoQ10 and the diet with high ME + $7.5 \mathrm{mg} C o Q 10 s$. Hatchability of fertile eggs \% was significantly $(P \leq 0.05)$ high due to feeding on diet supplemented with $7.5 \mathrm{mg}$ CoQ10s in comparison with those fed diet supplemented with CoQ10n or free CoQ10. Fertility percentage was improved as a result of dietary supplementation of CoQ10s to the diet which contains $2800 \mathrm{Kcal} / \mathrm{kg}$ diet. Also, there was an insignificant increase in hatchability of set eggs\% due to addition $7.5 \mathrm{mg}$ CoQ10s / kg diet. The progressive motility \% of sperm and blood serum triglyceride were significantly $(P \leq 0.05)$ improved by decreasing $M E$ content in the cock's diet.

Interaction between $M E$ and CoQ10 had significantly effect $(P \leq 0.05)$ on final $B W$ where, final $B W$ of cocks fed diet contained low ME (2800 Kcal) +7.5 mg synthetic CoQ10 (CoQ10s)/ $\mathrm{kg}$ diet was significantly $(P \leq 0.05)$ decreased as compared to those fed diets contained low ME without CoQ10 and the diet with high ME + $7.5 \mathrm{mg}$ CoQ10s. 
However, the interaction between low level of $M E$ and $7.5 \mathrm{mg}$ CoQ10s caused to improve significantly $(P \leq 0.05) R B C, H E B, H$, and $H / L$ as compared to the other dietary interaction treatments. However, all dietary interactions treatment groups were recorded significantly $(P \leq 0.05)$ the lowest value of serum cholesterol when compared to the diet contained high ME without CoQ10. The ratio of HDLLDL was significantly $(P \leq 0.05)$ increased by feeding on diet contained high $M E$ supplemented with CoQ10n and the diet contained low ME without CoQ10 as compared to the other interaction treatments. The results illustrated that the beneficial influence of CoQ10 supplementation in diet contained low level of ME to improve the histological studies of Sinai cocks testes.

Conclusively, it could be concluded that there were a beneficial affects due to adding $7.5 \mathrm{mg}$ CoQ10s / Kg diet contained low ME level, and therefore it could be used a functional feed additive in diets of Sinai cocks to maximize the reproductive and economical performance during the period from 40 to 56 weeks of age.

Key words: Coenzyme Q10, supplementation, reproductive performance, chicken cocks, energy diet levels.

\section{INTRODUCTION}

The Nutrition is one of the most important environmental factors affecting reproductive performance in any system of poultry production. It should be mentioned that the effective level of energy is different between various breeds (Lippense et al., 2002). Hussein et al. (2010) reported that the optimal dietary protein and metabolizable energy levels for Sinai laying hens are $15 \% \mathrm{CP}$ and $2750 \mathrm{kcal} \mathrm{ME} / \mathrm{kg}$ diet to achieve acceptable productive and reproductive performance during the period from 25 to 49 weeks of age, but there is no information on nutritional requirements of local Sinai cocks. It is well established that hens generally adjust their feed intake according to their energy requirements.

Chick's production highly depends on flock fertility. As it has been reported, semen quality can impact egg fertility and subsequently egg hatchability (Brillard, 2003). According to Sarah (2001), fertility in a breeder flock can be improved by using males with high sperm quality. Upendra et al. (2000) reported that semen quality is positively correlated with percentage of fertile eggs and hatchability. The semen quality in poultry gives an excellent indicator of their reproductive potential (Peters et al., 2004). Sperm viability, 
concentration and motility are the major components of routine quality assessment (Nering et al., 2009). These components are under the control of many factors including feeding.

Dietary energy level has been reported by many authors to affect performance trait such as body weight, delayed sexual maturity, semen production and quality in the male bird (Romero-Sanchez et al., 2008 and Brière et al., 2011). Kirby et al. (1996) reported that increase in calorie intake may lead to an increase in testes weight with no apparent increase in spermatogenic efficiency. Adequate nutrition is therefore essential to maintain the breeding flock in good reproductive condition (Brière et al., 2011).

Coenzyme Q10 is lipid-soluble compound present in endomembrane of cells as well as in mitochondria, it takes part in the mitochondrial respiratory chain, accepts and transports electrons to oxygen, and at the same time the proton gradient promotes ATP synthesis (Ernster and Dallner, 1995). Coenzyme Q10 has a fundamental role in cellular bioenergetics as a cofactor in the mitochondrial electron transport chain (respiratory chain) and is therefore essential for the production of ATP (Hemmin and Rajak 2006). The redox functions of $\mathrm{CoQ}_{10}$ extend beyond its role in the mitochondria. Furthermore, $\mathrm{CoQ}_{10}$ in its reduced form as the hydroquinone (called ubiquinol) is a potent lipophilic antioxidant and is capable of recycling and regenerating other antioxidants such as tocopherol and ascorbate (Hemmin et al. 2006). Its antioxidant properties contribute to prevention of lipid per-oxidation. It has been found to be efficient in preventing LDL oxidation which is an important step in evolution of atherosclerosis (Yokoyama et al., 1996).

Therefore, the aim of the present study was to evaluate the effect of dietary energy level and CoQ10 supplementation on body weight, testicular weight, semen characteristic, fertility and subsequent hatchability of local Sinai cocks.

\section{MATERIALS AND METHODS}

\section{Bird's management and diets:}

The current study was conducted at El-Serw Poultry Research Station, Animal Poultry Research Institute, Agriculture Research Center, Ministry of Agriculture, Egypt. Fifty four of Sinai cocks 40 weeks of age were randomly assigned to six dietary treatments in an experiment that was conducted from 40 to 56 weeks of age. At the onset of the experiment, cocks were weighed and assigned to $2 \times 3$ completely randomized design based on two levels of energy (2940 and $2800 \mathrm{Kcal} / \mathrm{Kg}$ diet) and synthetic source of Coenzyme Q10

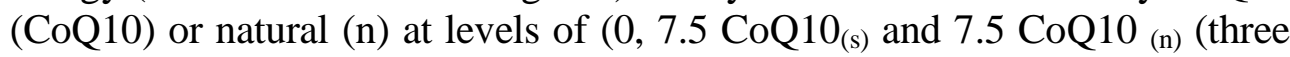


replicates per each and three cocks per each replicate). The three replicates were fed one of the six dietary treatments. Each replicate comprised three adjacent cages with one cock /cage $(60 \mathrm{~cm}$ long x $50 \mathrm{~cm}$ wide $\mathrm{x} 60 \mathrm{~cm}$ high). Birds were provided with programmed lighting (16L: 8D). The experimental diets were as the following:

1- The basal diet containing $2940 \mathrm{Kcal} / \mathrm{Kg}$ diet and $15 \% \mathrm{CP}$ according to NRC (1994) as shown in Table 1.

2- The basal supplemented with 7.5mg COQ10 synthetic(7.5mg CoQ10 $\left(0_{(\mathrm{s})}\right)$.

3- The basal die supplemented with $7.5 \mathrm{mg}$ CoQ10 from 3.0\% soybean oil (7.5 mg CoQ10 (n) $)$.

4- The diet containing low level of ME (2800 Kcal/ Kg diet) and $15 \% \mathrm{CP}$.

5- The diet containing low ME supplemented with $7.5 \mathrm{mg}$ CoQ10 synthetic $\left(7.5 \mathrm{mg} \mathrm{CoQ} 10_{(\mathrm{s})}\right)$,

6- The diet containing low level ME supplemented with $7.5 \mathrm{mg}$ CoQ10 from $3 \%$ soybean oil $(7.5 \mathrm{mg}$ CoQ10 $(\mathrm{n})$,

\section{Productive and Reproductive traits:}

1. Body weight (BW) was recorded at the beginning and at the end of the experiment. Also, feed intake was recorded daily.

2. Semen quality traits were measured where; three cocks were used from each treatment group by a positive reaction to dorso-abdominal massage for artificial collection of semen, Semen was collected during the experimental period, and then ejaculate volume, sperms motility and concentration were determined for each cock.

3. In addition, natural insemination was used in this study, where at 54 weeks of age each one male was transported to 10 hens, which were fed the same basal layer diet (16\% CP and $2750 \mathrm{ME})$ then eggs from each treatment were collected for 5 days. The eggs were set in incubator. Fertility and hatchability percentages were calculated and hatched chicks were weighed.

\section{Carcass traits:}

At the end of the experimental period, two cocks per each treatment were taken, weighed, slaughtered then the relative weight of carcass, heart, liver, edible parts, gizzard and testis were determined, where these variables were expressed as relative to their live body weight.

\section{Serum biochemical and hematological parameters:}

Blood samples were collected randomly in vial tubes containing EDTA as anticoagulant. Differential white blood cells (WBC) counts were 
Table (1): Composition and calculated nutrients of experimental diets

\begin{tabular}{|c|c|c|c|c|c|c|}
\hline \multirow{3}{*}{ Ingredients } & \multicolumn{6}{|c|}{ Dietary ME (Kcal/Kg diet) } \\
\hline & \multicolumn{3}{|c|}{ Control } & \multicolumn{3}{|c|}{ Low energy diet } \\
\hline & $\operatorname{CoQ}_{10}$ & $\begin{array}{l}\mathrm{CoQ10} \\
7.5 \mathrm{mg} / \mathrm{kg}\end{array}$ & $\mathrm{CoQ10}_{(0)}$ & $\mathrm{CoQ10}_{(0)}$ & $\begin{array}{l}\mathrm{CoQ10}_{(\mathrm{s})} \\
7.5 \mathrm{mg} / \mathrm{kg}\end{array}$ & $\mathrm{CoQ10}_{(\mathrm{n})}$ \\
\hline Yellow corn & 73.2 & 73.2 & 63.70 & 68.00 & 68.00 & 58.70 \\
\hline $\begin{array}{l}\text { Soybean meal } \\
(44 \%)\end{array}$ & 20.25 & 20.25 & 19.95 & 19.80 & 19.80 & 20.00 \\
\hline Wheat bran & 2.50 & 2.50 & 8.00 & 6.50 & 6.50 & 10.60 \\
\hline Soybean oil & 0.0 & 0.0 & 3.0 & 0.0 & 0.0 & 3.0 \\
\hline Limestone & 2.0 & 2.0 & 2.0 & 2.0 & 2.0 & 2.0 \\
\hline $\begin{array}{l}\text { Di calcium } \\
\text { phosphate }\end{array}$ & 1.35 & 1.35 & 1.35 & 1.35 & 1.35 & 1.35 \\
\hline Salt & 0.30 & 0.30 & 0.30 & 0.30 & 0.30 & 0.30 \\
\hline Premix $^{1}$ & 0.3 & 0.3 & 0.3 & 0.3 & 0.3 & 0.3 \\
\hline Dl-methionine & 0.05 & 0.05 & 0.05 & 0.05 & 0.05 & 0.05 \\
\hline Lysine & 0.05 & 0.05 & 0.05 & 0.05 & 0.05 & 0.05 \\
\hline Sand & 0.0 & 0.0 & 1.30 & 1.65 & 1.65 & 3.70 \\
\hline Total & 100 & 100 & 100 & 100 & 100 & 100 \\
\hline \multicolumn{7}{|c|}{ Calculated nutritional values $^{2}$} \\
\hline Crude protein $\%$ & 15.0 & 15.0 & 14.96 & 15.0 & 15.0 & 14.98 \\
\hline $\mathrm{ME}(\mathrm{Kcal} / \mathrm{Kg})$ & 2940 & 2940 & 2938 & 2808 & 2808 & 2804 \\
\hline Crude fat $\%$ & 3.44 & 3.44 & 3.80 & 3.72 & 3.72 & 3.98 \\
\hline Crude fiber $\%$ & 3.19 & 3.19 & 6.10 & 3.14 & 3.14 & 5.95 \\
\hline Calcium \% & 1.14 & 1.14 & 1.15 & 1.14 & 1.14 & 1.15 \\
\hline Av. phosphorus \% & 0.38 & 0.38 & 0.39 & 0.39 & 0.39 & 0.39 \\
\hline T. phosphorus\% & 0.59 & 0.59 & 0.61 & 0.61 & 0.61 & 0.62 \\
\hline Methionine(Meth)\% & 0.33 & 0.33 & 0.33 & 0.33 & 0.33 & 0.33 \\
\hline Lysine \% & 0.83 & 0.83 & 0.83 & 0.83 & 0.83 & 0.84 \\
\hline Meth + Cystine \% & 0.59 & 0.59 & 0.59 & 0.59 & 0.59 & 0.59 \\
\hline Price $(\mathrm{LE} / \mathrm{kg})^{3}$ & 4.953 & 4.955 & 5.05 & 4.814 & 4.816 & 4.922 \\
\hline
\end{tabular}

1- Each $3 \mathrm{~kg}$ of Vit .and Min. premix contains 100 million IUVit $\mathrm{A} ; 2$ million IU Vit. $\mathrm{D}_{3} ; 10$

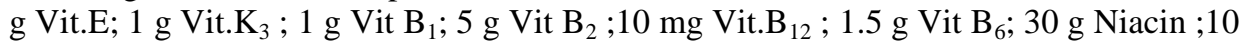
g Pantothenic acid ; $1 \mathrm{~g}$ Folic acid;50 mg Biotin ; $300 \mathrm{~g}$ Choline chloride; $50 \mathrm{~g}$ Zinc; $4 \mathrm{~g}$ Copper; $0.3 \mathrm{~g}$ Iodine ; $30 \mathrm{~g}$ Iron; $0.1 \mathrm{~g}$ Selenium; 60g Manganese ;0.1 g Cobalt; and carrier $\mathrm{CaCO} 3$ to $3000 \mathrm{~g}$.

2- According to feed composition Tables of animal and poultry feedstuffs used in Egypt (2001).

3- Price of one $\mathrm{kg}$ (LE) at time of experiment for different ingredients: yellow corn, 3.95; Soy been meal, 8.0; Wheat bran, 2.42; Di-calcium, 10.8; limestone, 0.20; Vit. \& Min., 60.0; Na cl, 0.50 and Methionine, 70.0; Lysine, 40; Coenzyme Q10 750mg, 21.25.

performed by using standard avian guidelines introduced by Ritchie et al. (1994). Total white blood cells were determined by the Unopett method (Campbell, 1995). Heterophils (H) and lymphocytes (L) were counted in different microscopic fields in a total of $200 \mathrm{WBC}$ by the same person, and 
the H: L ratios were calculated (Gross and Siegel, 1986). In addition, anther blood samples (without EDTA) were centrifuged at $4000 \mathrm{rpm}$ for 15 minutes, to separate the serum for biochemical analysis, which include cholesterol high density lipoprotein and low density lipoprotein by using commercial kits.

\section{Histological examination:}

At the end of the experimental period, two cocks per each treatment were taken, weighed, slaughtered then regarding histological examination of testis, testis were immediately fixed in $10 \%$ formalin saline. After fixation, samples were dehydrated in alcohol, cleared in xylene and embedded in paraffin wax. Paraffin sections (5-7 $\mu$ thick) were prepared and stained with hematoxline and eosin. Eventually, the sections were examined microscopically (Riddell, 1987).

\section{Economic efficiency:}

At the end of the study, economical efficiency for hatched chicks from Sinai hens were met by cocks fed diets containing different levels of Metabolizable energy and Coenzyme Q10 was expressed calculated using the following equation:

Economic efficiency $(\%)=($ Net return LE/Total feed cost LE $) \times 100$.

\section{Statistical analysis:}

Data were statistically analyzed using General Linear Models Procedure of the SPSS program (2008). A factorial design $2 \times 3$ was used, considering the ME and CoQ10 levels as the main effects and the following model according to Snedecor and Cochran (1982) was used to study the effect of main factors and interaction between ME and CoQ10 on parameters investigated as follows:

$$
Y i j k=\mu+T i+R j+(T R) i j+e i j k
$$

Where: Yijk=An observation; $\mu=$ Overall mean; $\mathrm{Ti}=$ Effect of $\mathrm{ME}$ level( $\mathrm{i}=1$ and 2 ); $\mathrm{Rj}=$ effect of CoQ10 level; $\mathrm{j}=(1,2$ and 3$) ; \mathrm{TRij}=$ Effect of interaction between $\mathrm{ME}$ and $\mathrm{CoQ} 10$ (ij= 1,2...6); and ejik= Experimental error

Differences between treatments were subjected to Duncan's Multiple Range- test (Duncan, 1955).

\section{RESULTS AND DISCUSSION:}

\section{Productive traits:}

Results concerned final live body weight (BW), daily feed intake and viability $\%$ are found in Table 2 . The results illustrated that decreasing 
Table (2): Some productive traits of Sinai cocks fed diets containing different levels of Metabolizable energy and Coenzyme Q10

\begin{tabular}{|c|c|c|c|c|c|}
\hline \multirow{2}{*}{\multicolumn{2}{|c|}{ Factors }} & \multicolumn{4}{|c|}{ Some productive traits } \\
\hline & & $\begin{array}{c}\text { Initial body } \\
\text { weight(g) }\end{array}$ & $\begin{array}{c}\text { Final body } \\
\text { weight(g) }\end{array}$ & $\begin{array}{c}\text { Feed } \\
\text { intake }(g)\end{array}$ & $\begin{array}{c}\text { Viability } \\
\%\end{array}$ \\
\hline \multicolumn{4}{|c|}{ Energy Kcal/kg diet (ME) } & & \\
\hline \multicolumn{2}{|c|}{ E1 ( 2940) } & 1977 & $2033 a$ & 96.5 & $77.8^{\mathrm{b}}$ \\
\hline & 1959 & $1963 b$ & 101.6 & $92.6^{\mathrm{a}}$ \\
\hline \multicolumn{2}{|c|}{ \pm SE mean } & 19.88 & 34.23 & 2.67 & 5.86 \\
\hline \multicolumn{2}{|c|}{ Significant test } & $\mathbf{0 . 5 2 7}$ & 0.173 & 0.194 & 1.000 \\
\hline \multicolumn{4}{|c|}{ Co $Q 10 \mathrm{mg} / \mathrm{Kg} \operatorname{diet}(\mathrm{mg} / \mathrm{kg})($ Co Q10) } & & \\
\hline & 1980 & 2085 & 98.0 & 83.3 \\
\hline \multicolumn{2}{|c|}{ Co Q10 (s) } & 1963 & 1964 & 101.5 & 88.9 \\
\hline \multicolumn{2}{|c|}{ Co Q10 (n) } & 1960 & 1973 & 97.6 & 83.3 \\
\hline \multicolumn{2}{|c|}{$\pm \mathrm{SE}$ mean } & 24.35 & 41.92 & 3.26 & 7.17 \\
\hline \multicolumn{2}{|c|}{ Significant test } & $\mathbf{0 . 8 3 2}$ & 0.253 & 0.665 & 0.821 \\
\hline \multicolumn{6}{|c|}{ Interaction $(\mathrm{ME}) x(\mathrm{CoQ} 10)$} \\
\hline \multirow{3}{*}{$\begin{array}{l}\stackrel{+}{g} \\
\text { ปे }\end{array}$} & COQ $(0)$ & 1999 & $2039^{\text {ab }}$ & 96.7 & 77.8 \\
\hline & $\operatorname{CoQ}\left(7.5_{\mathrm{s}}\right)$ & 1972 & $2077^{\mathrm{a}}$ & 99.2 & 77.8 \\
\hline & $\operatorname{CoQ}(7.5 n)$ & 1967 & $1983^{\mathrm{ab}}$ & 93.5 & 77.8 \\
\hline \multirow{3}{*}{ 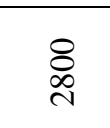 } & COQ $(0)$ & 1961 & $2077^{\mathrm{a}}$ & 99.4 & 88.9 \\
\hline & $\operatorname{CoQ}\left(7.5_{s}\right)$ & 1961 & $1850^{\mathrm{b}}$ & 103.8 & 100.0 \\
\hline & $\operatorname{CoQ}(7.5 n)$ & 1950 & $1962^{\mathrm{ab}}$ & 101.8 & 88.9 \\
\hline \multicolumn{2}{|c|}{ \pm SE mean } & 34.43 & 59.29 & 4.62 & 10.14 \\
\hline \multicolumn{2}{|c|}{ Significant test } & 0.913 & 0.129 & 0.697 & 0.571 \\
\hline
\end{tabular}

a,b :Means in the same column bearing different superscripts are significantly different $(\mathrm{P} \leq 0.05)$.

$\mathrm{NS}=$ Non-significant; $*=\mathrm{P} \leq 0.05, \mathrm{SE}$ mean $=$ Standard error mean.

dietary metabolizable energy (ME) from 2940 to $2800 \mathrm{Kcal} / \mathrm{kg}$ diet caused to a significant $(\mathrm{P} \leq 0.05)$ decrease in final live $\mathrm{BW}$ at the end of study at 56 week of age by about $3.44 \%$. While, insignificant changes were observed due to supplementation of $7.5 \mathrm{mg}$ synthetic or natural Coenzyme Q10 (CoQ10) / kg cocks' diet. On the other hand, the interaction between ME and CoQ10 had significantly $(\mathrm{P} \leq 0.05)$ effect on final BW. Final BW of cocks fed diet contaminating low ME $(2800 \mathrm{Kcal})+7.5 \mathrm{mg}$ synthetic CoQ10 $(\mathrm{CoQ} 10 \mathrm{~s}) / \mathrm{kg}$ diet had significantly $(\mathrm{P} \leq 0.05)$ the lowest weight when compared with those fed diets containing the low ME without CoQ10 and the those fed a diet with the high ME + 7.5 mg CoQ10s.

No significant influence due to different dietary levels of ME, CoQ10 and their interaction between them on feed intake. In respect of viability\%, cocks receiving diet containing $2800 \mathrm{Kcal} / \mathrm{kg}$ diet recorded significantly 
$(\mathrm{P} \leq 0.05)$ the highest value of viability $\%$ by about $19 \%$ when compared to those fed diet containing higher level of energy. Statistically non-significant alternations were recorded in viability\% due to the feeding on diets supplemented with CoQ10 and interaction between ME and CoQ10. However, the most remarkable is that the highest viability \% value $(100 \%)$ was observed with the diet contained moderated ME and supplemented with $7.5 \mathrm{mg}$ synthetic CoQ10/kg diet.

Regarding final live BW, the results in the current study were consist with Balnave and Robinson (2000) who observed that body weight gain increased with increasing dietary ME level (2500, 2700 and $2900 \mathrm{kcal} \mathrm{ME} / \mathrm{kg}$ ) in the diet for Brown layer. In addition, the present results were in agreement with those of Geng et al., (2004) who mentioned that BW was not significantly $(\mathrm{P} \geq 0.05)$ influenced by CoQ10 supplementation in diets' broiler.

In respect of total feed intake, the current results are in line with Grobas et al. (1999) who indicated that the increase of $33 \mathrm{kcal} / \mathrm{kg}$ of dietary energy decreased feed intake by $1 \%$. In addition, this is in agreement with Harms et al. (2000) who showed that birds fed the diets containing 2519 $\mathrm{kcal} / \mathrm{kg}$ had $8.5 \%$ more feed intake than those fed the diets containing 2798 $\mathrm{kcal} / \mathrm{kg}$.

The likely reasons for this improvement in viability\% results due to decrease $\mathrm{ME}$ by about $140 \mathrm{Kcal} / \mathrm{kg}$ diet and the dietary supplementation of $7.5 \mathrm{mg}$ synthetic CoQ10/kg diet contained moderate ME are speculative. Initially, Sinai cocks at 40 weeks of age already reached the average body weight of this strain (1950 g /cock); consequently any increase above body weight indicates that cocks tend to deposit abdominal fat which considered a disadvantage with cocks. Thus, from these results the decreasing ME content in diets for Sinai cocks during the period from 40- 56 weeks of age could be successful management to improve the viability \%. Moreover, the study conducted by Kikusato et al., (2015) illustrated that dietary supplementation with CoQ10 attenuates the muscular oxidative damage, suggesting that this may be due to the suppression of mitochondrial reactive oxygen species (ROS) production. Also, CoQ10 is also known as a very effective antioxidant (Bentinger et al., 2007), protecting against lipid peroxidation, DNA, and protein oxidation and capable of functioning synergistically with other antioxidants (Challem, 2005).

\section{Hatching traits:}

The effects of ME, Co Q10 and their interaction on reproductive performance are shown in Table (3). Results obtained clearly observed that the values of fertility $\%$, hatchability of set and fertile eggs $\%$ and chick 
Table (3): Hatching traits of eggs from Sinai hens were met by cocks fed diets containing different levels of Metabolizable energy and Coenzyme Q10

\begin{tabular}{|c|c|c|c|c|c|}
\hline \multirow{2}{*}{\multicolumn{2}{|c|}{ Factors }} & \multicolumn{4}{|c|}{ Some reproductive traits } \\
\hline & & $\begin{array}{c}\text { Fertility } \\
\%\end{array}$ & $\begin{array}{l}\text { Hatchability } \\
\text { of set eggs\% }\end{array}$ & $\begin{array}{c}\text { Hatchability of } \\
\text { fertile eggs \% }\end{array}$ & $\begin{array}{c}\text { Chick weight } \\
\text { (g) }\end{array}$ \\
\hline \multicolumn{6}{|c|}{ Energy Kcal/kg diet (ME) } \\
\hline \multirow{2}{*}{\multicolumn{2}{|c|}{$\begin{array}{l}\text { E1 } 1940 \\
\text { E2 } 2800\end{array}$}} & 94.3 & 82.5 & 87.5 & 33.8 \\
\hline & & 96.5 & 84.8 & 87.9 & 34.1 \\
\hline \multicolumn{2}{|c|}{ Pooled SEM } & 2.33 & 2.65 & 1.72 & 0.35 \\
\hline \multicolumn{2}{|c|}{ Significance teat } & 0.507 & 0.547 & 0.873 & 0.493 \\
\hline \multicolumn{6}{|c|}{ Co $Q 10 \mathrm{mg} / \mathrm{Kg} \operatorname{diet}(\mathrm{mg} / \mathrm{kg})($ Co Q10) } \\
\hline \multirow{3}{*}{\multicolumn{2}{|c|}{$\begin{array}{l}0.0 \\
7.5 \text { syncretic }\left(7.5_{\mathrm{s}}\right) \\
7.7 \text { natural }\left(7.5_{\mathrm{n}}\right)\end{array}$}} & 96.3 & 82.9 & $86.1 \mathrm{~b}$ & 33.7 \\
\hline & & 94.6 & 87.8 & $92.7 \mathrm{a}$ & 33.5 \\
\hline & & 95.4 & 80.3 & $84.2 b$ & 34.6 \\
\hline \multicolumn{2}{|c|}{ Pooled SEM } & 2.86 & 3.25 & 2.10 & 0.42 \\
\hline \multicolumn{2}{|c|}{ Significance test } & 0.923 & 0.294 & 0.034 & 0.191 \\
\hline \multicolumn{6}{|c|}{ Interaction $(\mathrm{ME}) x(\mathrm{CoQ} 10)$} \\
\hline \multirow{3}{*}{ 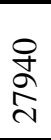 } & 0.0 & 95.8 & 82.7 & 86.3 & 34.1 \\
\hline & $\operatorname{CoQ}(7.5 \mathrm{~s})$ & 92.6 & 85.6 & 92.5 & 33.8 \\
\hline & $\operatorname{CoQ}\left(7.5_{n}\right)$ & 94.4 & 79.2 & 83.6 & 33.4 \\
\hline \multirow{3}{*}{ 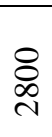 } & 0.0 & 96.7 & 83.0 & 85.9 & 33.3 \\
\hline & $\operatorname{CoQ}\left(7.5_{\mathrm{s}}\right)$ & 96.7 & 90.0 & 93.0 & 33.2 \\
\hline & $\operatorname{CoQ}\left(7.5_{n}\right)$ & 96.3 & 81.5 & 84.7 & 35.8 \\
\hline \multicolumn{2}{|c|}{ Pooled SEM } & 4.04 & 4.59 & 2.98 & 0.60 \\
\hline \multicolumn{2}{|c|}{ Significance test } & 0.773 & 0.054 & 0.011 & 0.058 \\
\hline
\end{tabular}

$\mathrm{a}, \mathrm{b}$ :Means in the same column bearing different superscripts are significantly different $(\mathrm{P} \leq 0.05)$.

$\mathrm{NS}=$ Non-significant $*=\mathrm{P} \leq 0.05, \mathrm{SE}$ mean $=$ Standard error mean.

weight of hatch were nearly similar and no significant effect was observed due to decrement ME by about $140 \mathrm{Kcal} / \mathrm{kg}$ diet, adding $7.5 \mathrm{mg}$ CoQ10s or CoQ10n (natural) and interaction among them except for hatchability of fertile eggs \% where, it tend to be significantly $(\mathrm{P} \leq 0.05)$ higher in eggs produced from hens were fertilized by cocks fed diet supplemented with 7.5 mg CoQ10s than those fed diet supplemented with CoQ10n or free CoQ10. However, it is evident that the diet contained ME $2800 \mathrm{Kcal} / \mathrm{kg}$ diet resulted in an insignificant $(\mathrm{P} \geq 0.05)$ increase in fertility \% by about $2.33 \%$ when compared to the diet contained high ME $(2940 \mathrm{Kcal} / \mathrm{kg}$ diet $)$. In addition, fertility \% increased insignificantly $(\mathrm{P} \geq 0.05)$ as a result of addition of CoQ10s to the diet which contain $2800 \mathrm{Kcal} / \mathrm{kg}$ diet. Also, there was an 
insignificant $(\mathrm{P} \geq 0.05)$ increase in hatchability of set eggs\% with addition $7.5 \mathrm{mg}$ CoQ10s / kg diet compared to the diet was high or low in ME.

The improvement in fertility $\%$ as a result of feeding on diets moderate in ME and supplemented with $7.5 \mathrm{mg}$ CoQ10s $/ \mathrm{kg}$ diet may be due to different mechanisms, initially, Coenzyme Q10 is known as a very effective antioxidant (Bentinger et al., 2007), protecting against lipid peroxidation, DNA, and protein oxidation and capable of functioning synergistically with other antioxidants (Challem, 2005).

According to Ravie and Lake, (1985) in birds the phospholipids of spermatozoa are characterized by extremely high proportions of long chain, highly n-6 polyunsaturated fatty acids. The high degree of polyunsaturation typical of sperm lipids renders these gametes highly susceptible to lipid peroxidation, with the consequent risk of damage to cellular structures (Niki et al., 1993). In fact, peroxidative damage to spermatozoa is believed to be a major cause of male subfertility (Aitken, 1994). Thus, enhancement of the antioxidant capacity of semen by supplementation of antioxidants such as CoQ10 could present a major opportunity for improving male fertility. In accordance with Surai et al., (1997), who postulated that the beneficial consequences of an effective protection against lipid peroxidation of birds semen are likely as a result of two related mechanisms: (a) Defense against peroxidative damage is essential to maintain the structural integrity of the spermatozoa; (b) Minimization of lipid peroxidation will prevent any reduction in the concentrations of the functionally important $n-6$ polyunsaturated fatty acids of the semen phospholipids.

\section{Some carcass traits:}

The effect of dietary different levels of ME, CoQ10 and their interaction on carcass traits are shown in Table (4). No significant $(\mathrm{P} \geq 0.05)$ alternations was detected as a result of decrease ME by $140 \mathrm{Kcal} / \mathrm{kg}$ diet, addition CoQ10s or CoQ10n and interaction between them on carcass, heart, liver, edible parts and testis \%. However, gizzard\% was significantly $(\mathrm{P} \leq 0.05)$ increased by the high level of $\mathrm{ME}$ and addition $7.5 \mathrm{mg}$ CoQ10s $/ \mathrm{kg}$ diet. Also, the interaction between high ME and CoQ10s had significantly $(\mathrm{P} \leq 0.05)$ the highest gizzard\% compared to the diet without CoQ10.

The cocks fed diet supplemented with CoQ10 resulted in an improvement in gizzard\%. According to Hetland et al, (2005) the gizzard regulate the particle size of food entering the small intestine for downstream digestion. Also, the gizzard governs many physiological aspects, including 1) particle size reduction; 2) motility regulation; 3) control of feed flow and gastro duodenal refluxes; 4) enhancement of digestive secretions, including 
Table (4): Some carcass traits of local Sinai cocks fed diets containing different levels of Metabolizable energy and Coenzyme Q10

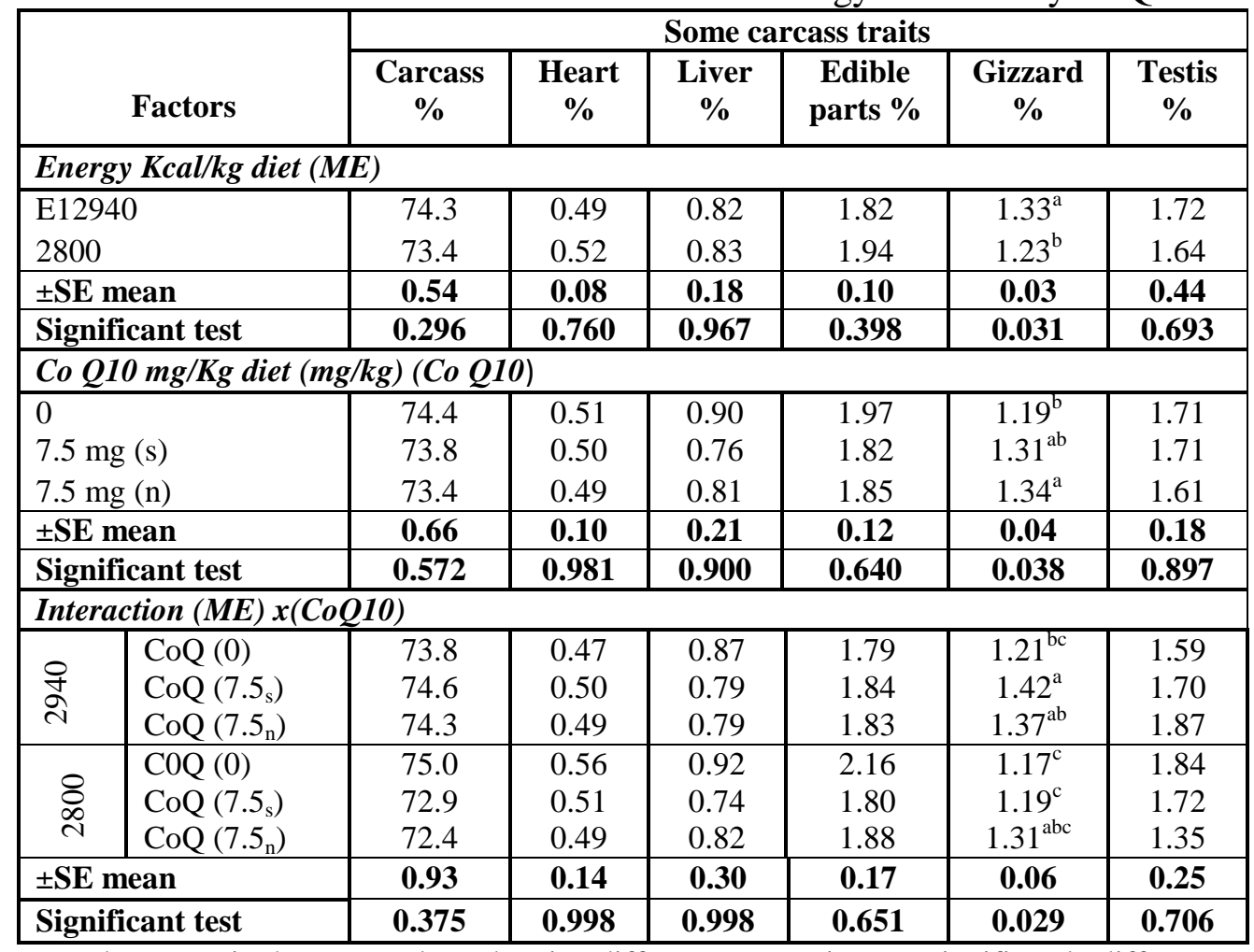

$\mathrm{a}, \mathrm{b}$ :Means in the same column bearing different superscripts are significantly different $(\mathrm{P} \leq 0.05)$.

NS = Non-significant $*=\mathrm{P} \leq 0.05, \mathrm{SE}$ mean $=$ Standard error mean.

$\mathrm{HCl}$, bile acid, and endogenous enzymes; and 5) synchronization of digestion and absorption processes (Mateos et al., 2012).

\section{Hematology, Semen quality and serum biochemical:}

The results in Table (5) showed insignificant $(\mathrm{P} \geq 0.05)$ effect due to cock's diets contained different levels of ME on blood hematology traits, but indeed, red blood cells (RBC) and hemoglobin (HGB) significantly $(\mathrm{P} \leq 0.05)$ increased due to decrease $\mathrm{ME}$ content in the diet. In respect of CoQ10, there was a significant $(\mathrm{P} \leq 0.05)$ improved in $\mathrm{RBC}, \mathrm{HGB}$, heterophil cells $(\mathrm{H})$ and $\mathrm{H} /$ lymphocytes $(\mathrm{L})$ due to addition $7.5 \mathrm{mg}$ CoQ10s or $\mathrm{CoQ} 10 \mathrm{n} / \mathrm{kg}$ diet. The same manner, interaction between moderate level of $\mathrm{ME}$ and $7.5 \mathrm{mg}$ CoQ10s significantly $(\mathrm{P} \leq 0.05)$ improved $\mathrm{RBC}, \mathrm{HEB}, \mathrm{H}$, and $\mathrm{H} / \mathrm{L}$ as compared to the other dietary interaction treatments. 
Table (5): Some blood hematology of local Sinai cocks fed diets containing different levels of Metabolizable energy and Coenzyme Q10

\begin{tabular}{|c|c|c|c|c|c|c|c|}
\hline \multirow{2}{*}{\multicolumn{2}{|c|}{ Factors }} & \multirow{2}{*}{$\begin{array}{c}\mathrm{RBC} \\
\left(\mathrm{x10}^{6} / \mathrm{m}\right)\end{array}$} & \multirow[b]{2}{*}{$\begin{array}{c}\text { HGB } \\
(\mathrm{g} / 100 \mathrm{~m})\end{array}$} & \multirow{2}{*}{$\begin{array}{c}\text { WBC } \\
\left(\times 10^{3} / \mathrm{m}\right)\end{array}$} & \multicolumn{2}{|c|}{ Count, \% } & \multirow[b]{2}{*}{$\mathbf{H} / \mathbf{L}$} \\
\hline & & & & & $\mathbf{H}$ & $\mathbf{L}$ & \\
\hline \multicolumn{8}{|c|}{ Energy $\mathrm{Kcal} / \mathrm{kg} \operatorname{diet}(\mathrm{ME})$} \\
\hline \multicolumn{2}{|c|}{ E1 2940} & $4.30^{b}$ & $14.67 \mathrm{~b}$ & 22.33 & 27.18 & 60.63 & 0.45 \\
\hline \multicolumn{2}{|c|}{ E2 2800} & $4.85^{\mathrm{a}}$ & $15.56 \mathrm{a}$ & 22.00 & 27.65 & 60.00 & 0.47 \\
\hline \multicolumn{2}{|c|}{ Pooled SEM } & 0.06 & 0.16 & 0.45 & 0.48 & 0.98 & 0.02 \\
\hline \multicolumn{2}{|c|}{ Significant test } & 0.000 & 0.000 & 0.611 & 0.506 & 0.66 & 0.632 \\
\hline \multicolumn{8}{|c|}{ Co $Q 10 \mathrm{mg} / \mathrm{Kg} \operatorname{diet}(\mathrm{mg} / \mathrm{kg})($ Co $Q 10)$} \\
\hline \multicolumn{2}{|c|}{0.0} & $4.28^{\mathrm{b}}$ & $14.67 \mathrm{~b}$ & 22.00 & $25.20^{\mathrm{b}}$ & $64.06^{\mathrm{a}}$ & $0.39^{c}$ \\
\hline \multicolumn{2}{|c|}{$7.5 \mathrm{~s}$} & $4.79^{\mathrm{a}}$ & $16.33 \mathrm{a}$ & 22.50 & $29.40^{\mathrm{a}}$ & $56.25^{\mathrm{b}}$ & $0.52^{\mathrm{b}}$ \\
\hline \multicolumn{2}{|c|}{$7.5 \mathrm{n}$} & $4.68^{\mathrm{a}}$ & $15.83 \mathrm{a}$ & 22.00 & $27.65^{\mathrm{a}}$ & $60.63^{\mathrm{a}}$ & $0.46^{\mathrm{b}}$ \\
\hline \multicolumn{2}{|c|}{ Pooled SEM } & 0.07 & $0.20 \mathrm{a}$ & 0.55 & 0.59 & 1.20 & 0.02 \\
\hline \multicolumn{2}{|c|}{ Significant test } & 0.001 & 0.000 & 0.766 & 0.001 & 0.002 & 0.001 \\
\hline \multicolumn{8}{|c|}{ Interaction $(\mathrm{ME}) x(\mathrm{Co} Q 10)$} \\
\hline \multirow{3}{*}{ શั } & 0.0 & $3.78^{\mathrm{c}}$ & $13.00^{\mathrm{d}}$ & 22.00 & $24.15^{\mathrm{c}}$ & $64.38^{\mathrm{a}}$ & $0.38^{\mathrm{c}}$ \\
\hline & $\operatorname{CoQ}\left(7.5_{s}\right)$ & $4.50_{\mathrm{b}}$ & $15.33^{\mathrm{c}}$ & 22.00 & $29.75^{\mathrm{a}}$ & $55.63^{c}$ & $0.54^{\mathrm{a}}$ \\
\hline & $\operatorname{CoQ}\left(7.5_{n}\right)$ & $4.65^{\mathrm{b}}$ & $15.67^{\mathrm{bc}}$ & 23.00 & $27.65^{\mathrm{ab}}$ & $61.88^{\mathrm{ab}}$ & $0.45^{\mathrm{abc}}$ \\
\hline \multirow{3}{*}{ 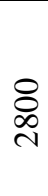 } & 0.0 & $4.77^{\mathrm{ab}}$ & $16.30^{\mathrm{b}}$ & 22.00 & $26.25^{\mathrm{bc}}$ & $63.75^{\mathrm{a}}$ & $0.41^{\mathrm{bc}}$ \\
\hline & $\operatorname{CoQ}\left(7.5_{\mathrm{s}}\right)$ & $5.07^{\mathrm{a}}$ & $17.30^{\mathrm{a}}$ & 23.00 & $29.05^{\mathrm{a}}$ & $\underset{c}{56.88^{b}}$ & $0.51^{\mathrm{a}}$ \\
\hline & $\operatorname{CoQ}\left(7.5_{n}\right)$ & $4.71^{\mathrm{b}}$ & $16.00^{\mathrm{bc}}$ & 21.00 & $27.65^{\mathrm{ab}}$ & $\underset{\mathrm{bc}}{59.38^{\mathrm{a}}}$ & $0.47^{\mathrm{ab}}$ \\
\hline \multicolumn{2}{|c|}{ Pooled SEM } & $\mathbf{0 . 1 0}$ & 0.28 & 0.78 & $\mathbf{0 . 8 3}$ & 1.70 & $\mathbf{0 . 0 3}$ \\
\hline \multicolumn{2}{|c|}{ Significant test } & 0.000 & 0.000 & 0.497 & 0.001 & 0.006 & 0.009 \\
\hline
\end{tabular}

; a,b :Means in the same column bearing different superscripts are significantly different $(\mathrm{P} \leq 0.05)$.

$\mathrm{HB}=$ Hemoglobin; $\mathrm{WBC}=$ White blood cells; $\mathrm{H}=$ Heterophils cells; $\mathrm{L}=$ Lymphocyte cells; $\mathrm{SEM}=$ Standard error mean NS $=$ non-significant $; *=\mathrm{P} \leq 0.05$

Results obtained on semen quality as shown in Table (6) illustrated that no significant $(\mathrm{P} \geq 0.05)$ effect of decreasing $\mathrm{ME}$ from 2940 to 2800 Kcal/ $\mathrm{kg}$ diet on semen quality and serum biochemical except for progressive motility \% (PM) and triglycerides in blood serum $(\mathrm{mg} / \mathrm{dl})$ where, both $\mathrm{PM} \%$ and triglycerides significantly $(\mathrm{P} \leq 0.05)$ improved by decreasing ME content in the cock's diet.

No significant effect due to addition $7.5 \mathrm{mg}$ CoQ10s or CoQ10n/ kg diet on semen quality. Regarding serum biochemical, there was a significant $(\mathrm{P} \leq 0.05)$ reduced in serum cholesterol in response to decrease $\mathrm{ME}$ and addition $7.5 \mathrm{mg}$ CoQ10s or $\mathrm{n} / \mathrm{kg}$ diet. Decreasing of ME, CoQ10s and all 
interactions led to significantly decrease $(\mathrm{P} \leq 0.05)$ in $\mathrm{LDL}$ cholesterol. In addition, HDL/ LDL were significantly $(\mathrm{P} \leq 0.05)$ increased due to interaction between high level of ME and7.5 mg CoQ10 $/ \mathrm{kg}$ and diet and due to moderate level of ME and CoQ10s as compared to the diet with high ME without addition CoQ10.

The results revealed that semen quality did not affect by the interaction between ME and CoQ10. On the other hand, all dietary interactions treatments recorded significantly $(\mathrm{P} \leq 0.05)$ the lowest value of serum cholesterol compared to the diet contained high ME without CoQ10. Also, blood serum of cocks fed diet contained low ME without addition CoQ10 showed significantly $(\mathrm{P} \leq 0.05)$ lower HDL and LDL \% than those fed the diet with the same ME but supplemented with CoQ10s. In respect of the ratio HDL/LDL, it was significantly $(\mathrm{P} \leq 0.05)$ increased by feeding on diet contained high $\mathrm{ME}$ supplemented with CoQ10n and the diet contained low ME without CoQ10 as compared to the other interaction treatments.

The improvement in PM \% by reduction level of ME may be due to a decrease in body weight (Table 2) which means the tendency to reduce abdominal fat deposition, which is considered advantage in those cocks. This is in agreement with (Cyrille et al., 2013) who reported that High dietary energy can reduce sperm production by decreasing the ability of spermatogonia to develop into spermatocyte. In addition, there was a beneficial effect on RBC, $\mathrm{HEB}, \mathrm{H}, \mathrm{H} / \mathrm{L}$, cholesterol, HDL and LDL as a result of addition CoQ10s to the moderate diet in ME; this improvement reflect the productive status of hens and may be attributed to coQ10 can be a very effective antioxidant (Bentinger et al., 2007), protecting against lipid peroxidation, DNA, and protein oxidation and capable of functioning synergistically with other antioxidants (Challem, 2005). Kikusato et al., (2015) illustrated that CoQ10 attenuates the muscular oxidative damage, suggesting that this may be due to the suppression of mitochondrial reactive oxygen species (ROS) production. Furthermore, Bhagavan and Chopra (2006) reported that CoQ10 acts as an electron carrier in the mitochondrial respiratory chain and as a lipid-soluble antioxidant.

\section{Histological examination:}

The results in Table (7) and microscopically plates (1 to 6) showed that both diet contained $2800 \mathrm{Kcal} / \mathrm{kg}$ diet and supplemented with $7.5 \mathrm{mg}$ CoQ10s or CoQ10n resulted in a grade excellent in thickness of spermatogenic layer and density of seminiferous tubules (ST) as compared to the diet contained $2940 \mathrm{kcal} / \mathrm{kg}$ diet and without CoQ10 where these traits were grade pass. While the opposite was true in respect of lumen of ST. Regarding shape 
Table (7): Effect of coenzyme Q10 supplementation on histological parameters of cock testes

\begin{tabular}{|l|c|c|c|c|c|c|}
\hline \multirow{2}{*}{\multicolumn{1}{|c|}{ Parameters }} & \multicolumn{5}{c|}{ Coenzyme Q10 } \\
\cline { 2 - 7 } & \multicolumn{3}{|c|}{ control } & \multicolumn{3}{c|}{ Low energy } \\
\cline { 2 - 7 } & $\begin{array}{c}\text { CoQ10 } \\
(\mathbf{0})\end{array}$ & $\begin{array}{c}\text { CoQ10 } \\
(\mathbf{s})\end{array}$ & $\begin{array}{c}\text { CoQ10 } \\
(\mathbf{n})\end{array}$ & $\begin{array}{c}\text { CoQ10 } \\
(\mathbf{0})\end{array}$ & $\begin{array}{c}\text { CoQ10 } \\
(\mathbf{s})\end{array}$ & $\begin{array}{c}\text { CoQ10 } \\
(\mathbf{n})\end{array}$ \\
\hline Treatment & $\mathrm{T} 1$ & $\mathrm{~T} 2$ & $\mathrm{~T} 3$ & $\mathrm{~T} 4$ & $\mathrm{~T} 5$ & T6 \\
\hline $\begin{array}{l}\text { Thickness of } \\
\text { spermatogenic layer }\end{array}$ & + & + & + & ++ & +++ & +++ \\
\hline Lumen of ST & ++ & +++ & ++ & + & + & + \\
\hline Density of ST & + & + & ++ & ++ & +++ & +++ \\
\hline Shape of ST & irregular & oval & oval & circular & oval & circular \\
\hline Size of ST & small & small & medium & medium & large & large \\
\hline
\end{tabular}

ST $=$ seminiferous tubules $;+=$ grade pass; $++=$ grade good $;+++=$ grade excellent

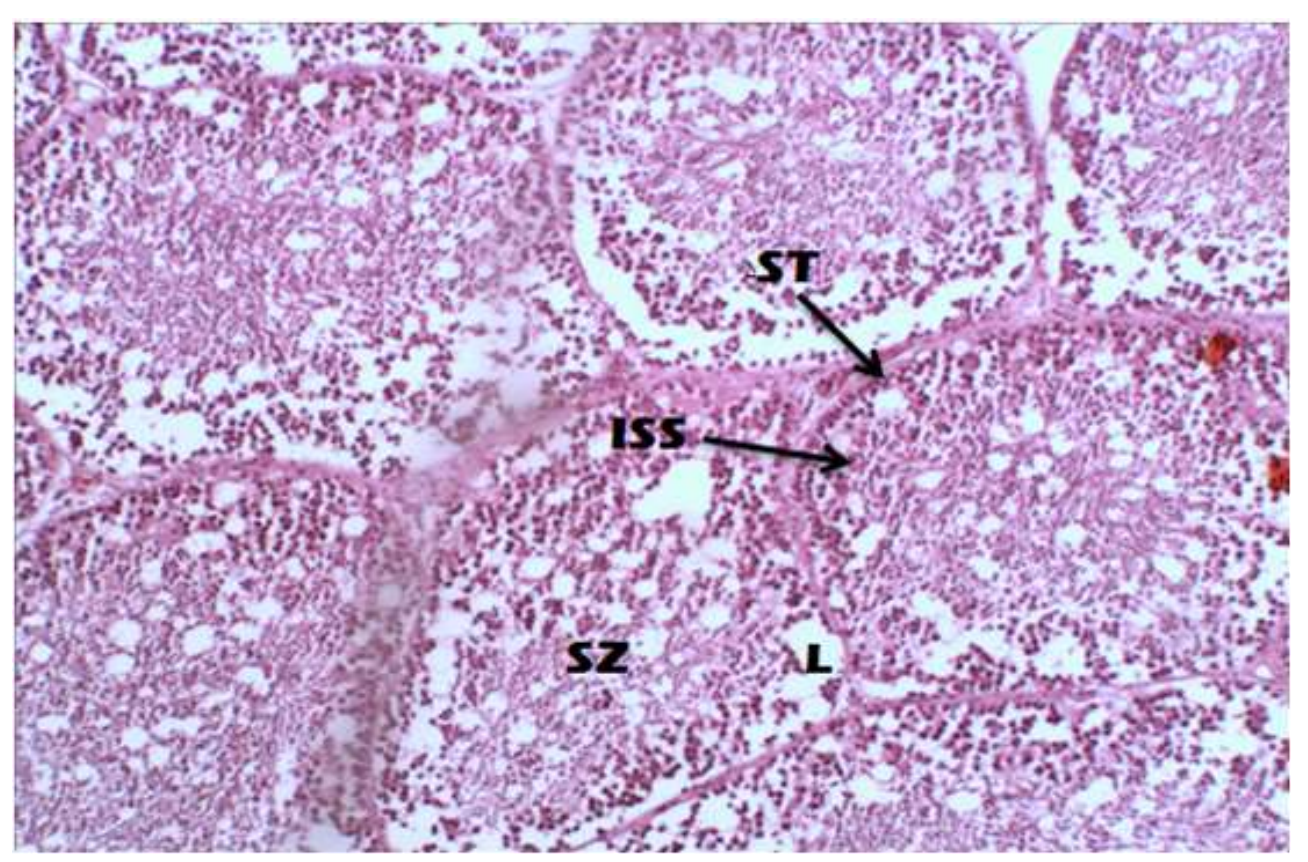

PLATE 1. (H and EX100) ST = Seminiferous tubules, $L=$ Lumen of Seminiferous tubules. ISS = Interstitial stroma, $\mathrm{SZ}=$ Spermatozoa Microphotograph of the testis showing decrease in thickness of spermatogenic layer of ST 


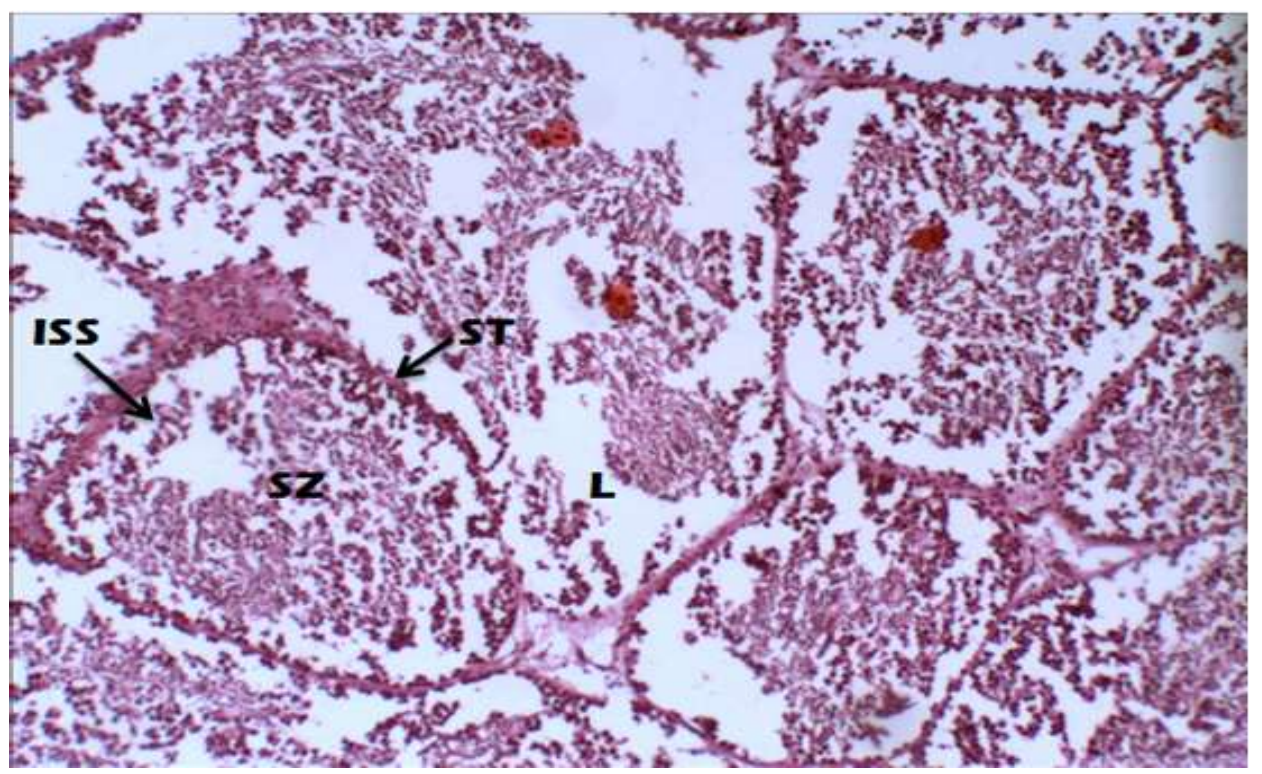

PLATE 2. (H and EX100) Microphotograph of the testis showing decrease in thickness of spermatogenic layer thickness of ST

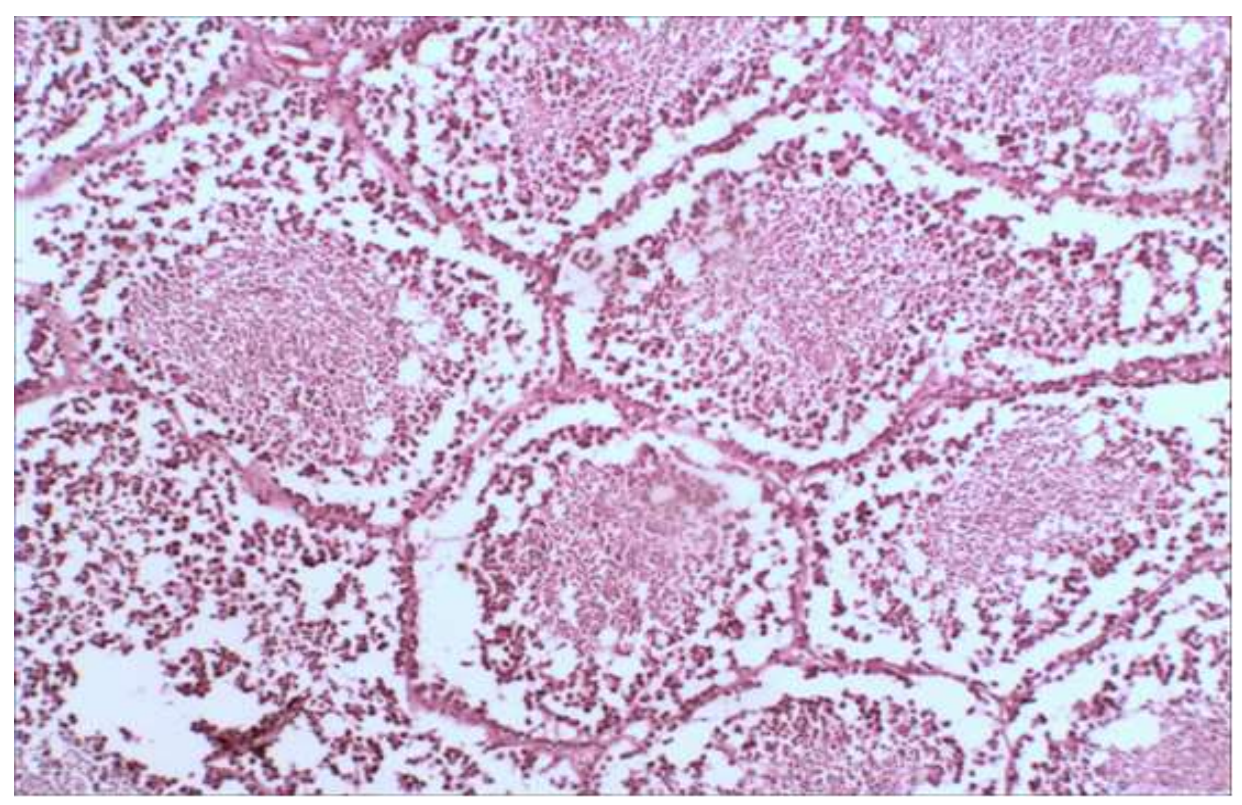

PLATE3. (H and EX100) Microphotograph of the testis showing decrease in number of ST. 


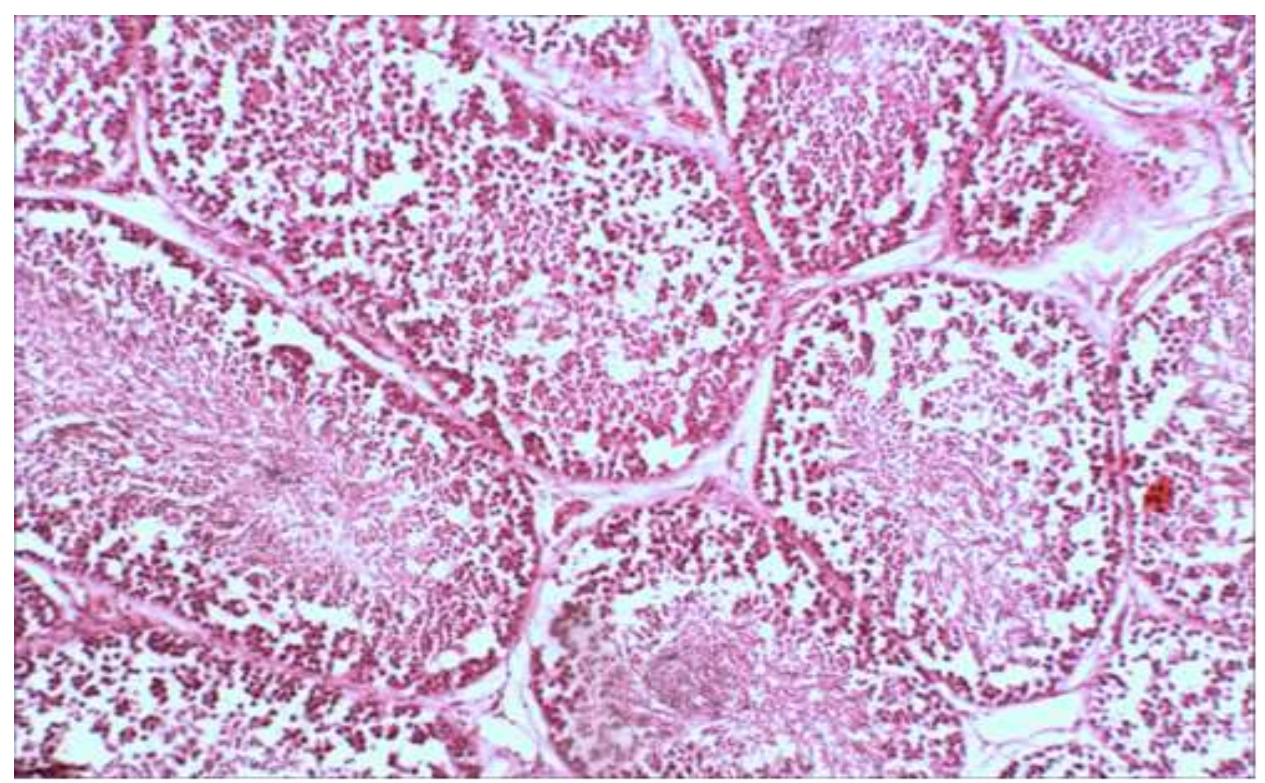

PLATE4. (H and EX100) Microphotograph of the testis showing high in spermatogenic layer thickness of ST.

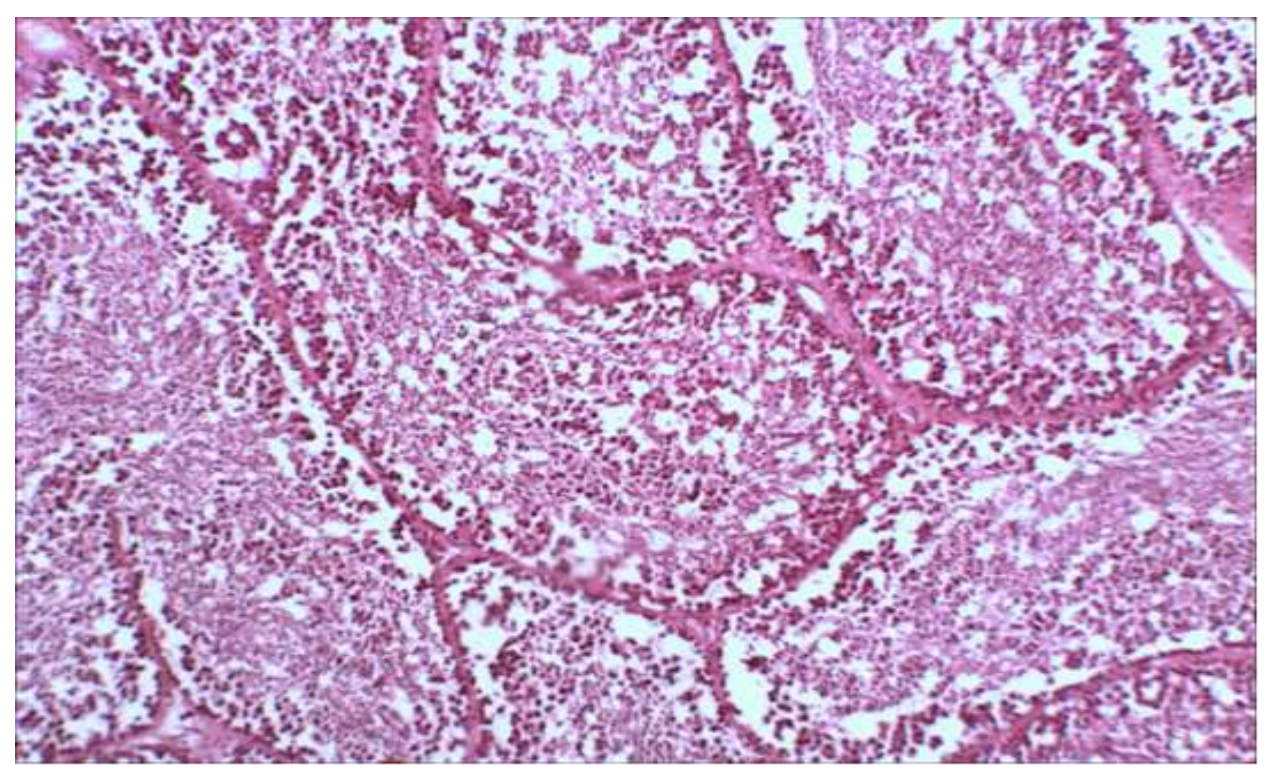

PLATE5. (H and E X100) Microphotograph of the testis showing high in ST density and spermatogenic layer thickness 


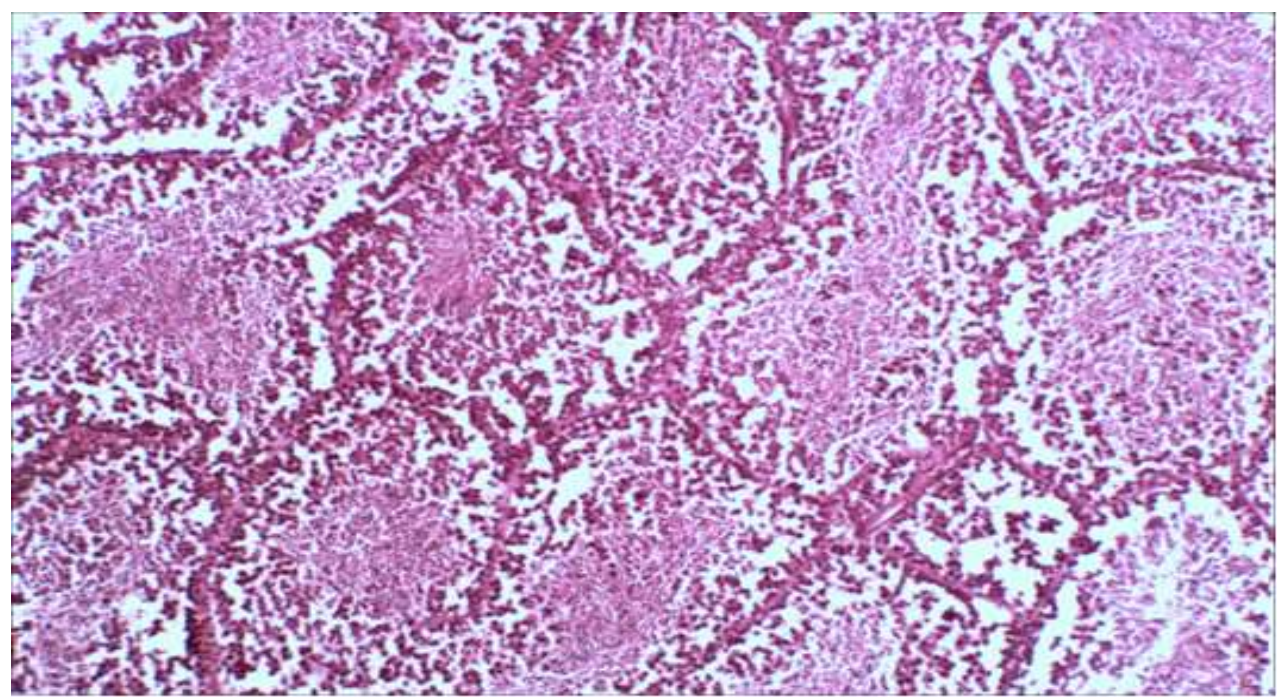

PLATE6. (H and E X100) Microphotograph of the testis showing High in ST density and narrow in the lumen of ST.

of ST, it was circular in cocks fed diet contained low energy and supplemented with CoQ10n while it was mall in those fed basal diet. Moreover, the size of ST was large due to feeding on low energy diet with CoQ10s or CoQ10n as compared to the basal diet. These results illustrated that the beneficial influence of CoQ10 supplementation in diet contained low level of ME to improve the histological studies of Sinai cocks testes.

\section{Economic efficiency (EEF):}

Results concerning the EEF of hatchability of set eggs (\%) as an influenced by dietary different levels of ME, CoQ10 and their interaction are presented in Table (8). No significant effect due to decreasing in ME, supplementation levels CoQ10 and their interaction on EEF, however, it can be noticed that EEF was insignificantly $(\mathrm{P} \geq 0.05)$ improved as a result of interaction between the diets group contained high or moderate $\mathrm{ME}$ and 7.5 $\mathrm{mg}$ CoQ10s $/ \mathrm{kg}$ diet (109.95\%) as compared to the other treatments.

Conclusively, these results referred that a beneficial affects due to addition $7.5 \mathrm{mg}$ CoQ10s $/ \mathrm{Kg}$ diet contained $2800 \mathrm{Kcal} \mathrm{ME} / \mathrm{kg}$ diet (moderate level) and it could be used a functional feed additive in diets of Sinai cocks to maximize the reproductive and economical performance during the period from 40 to 56 weeks of age. 
Table (8): Economic efficiency of hatched chicks from local Sinai hens were met by cocks fed diets containing different levels of Metabolizable energy and Coenzyme Q10

\begin{tabular}{|l|c|c|c|c|c|c|c|c|}
\hline \multicolumn{1}{|c|}{ Items } & $\begin{array}{c}\text { Price of } \\
\text { kg } \\
\text { feed/male } \\
\text { (LE) }\end{array}$ & $\begin{array}{c}\text { Price } \\
\text { of kg } \\
\text { feed/female } \\
\text { (LE) }\end{array}$ & $\begin{array}{c}\text { Total } \\
\text { cost } \\
\text { of } \\
\text { feed }\end{array}$ & $\begin{array}{c}\text { Hatch. } \\
\text { of set } \\
\text { eggs } \\
\text { \% }\end{array}$ & $\begin{array}{c}\text { Price } \\
\text { of } \\
\text { one } \\
\text { chick } \\
\text { (LE) }\end{array}$ & $\begin{array}{c}\text { Total } \\
\text { return } \\
\text { (LE) }\end{array}$ & $\begin{array}{c}\text { Net } \\
\text { return } \\
\text { (LE) }\end{array}$ & $\begin{array}{c}\text { EEF } \\
(\%)\end{array}$ \\
\hline Energy Kcal/Kg of diet( ME)
\end{tabular}

\section{REFERENCES}

Aitken R.J. (1994). A free radical theory of male infertility. Reproduction, Fertility and Development, 6: 19-24.

Balnave, D. and D. Robinson (2000). Energy requirements of imported Brown layer strains. A report for the rural industries research and development corporation. RIRDC Publication, No 00/179. 
Bentinger, M.; K. Brismar and G. Dallner (2007). The antioxidant role of coenzyme Q. Mitochondrion, 7:S41-S50.

Bhagavan, H.N. and R.K. Chopra (2006). Coenzyme Q10: absorption, tissue uptake, metabolism and pharmacokinetics. Free Rad-ical Research,40: 445-453

Brière, S., J.P. Brillard; M. Panheleux and P. Froment (2011) Alimentation, fertilité et bien-être des oiseaux re- producteurs domestiques: Des liens complexes. INRA Pro- ductions Animales, 24, 171-180.

Brillard, J.P. (2003). Practical aspects of fertility in poultry. World's Poultry Science, 59, 441-446.

Campbell, T.W. (1995). Avian Hematology and Cytology, Iowa State University Press, Ames, Iowa, USA. pp: 3-19.

Challem, J. (2005). Nutrients that enhance energy and prevent DNA damage. In: Feed Your Genes Right. pp. 41-53. John Wiley \& Sons, Hoboken, New Jersey.

Cyrille, T.; F. Ngoula; J. R. Kana; H. F. Defang; H. K. Mube and A. Teguia (2013). Effect of dietary energy level on body weight, testicular development and semen quality of local barred chicken of the western highlands of Cameroon. Advances in Reproductive Sciences, 1(3): 38-43.

Duncan, D.B. (1955). Multiple ranges and multiple f-test, Biometries 11: 1-42.

Ernster, L. and . Dallner (1995). Biochemical, physiological and medical aspects of ubiquinone function. Biochim Biophys Acta, 1271: 195-204.

Feed Composition Tables for Animals and Poultry Feedstuffs Used in Egypt (2001). Technical Bulletin No.,1, Central Lab. For Food and Feeds(CLFF) Ministry of Agric. Res. Cent., Egypt.

Geng,A.L.; Y. M. Guo and Y. Yang (2004). Reduction of ascites mortality in broilers by Coenzyme Q10. Poultry Science, 83:1587-1593.

Grobas, S.; J. Mendez; C. Deblas and G. G. Mateos (1999). Laying hen productivity as affected by energy, supplemental fat, and linoleic acid of the diet. Poultry Sci. 78:1542-1551.

Gross, W.B. and P.B. Siegel (1986). Effects of initial and second periods of fasting on heterophil/lymphocyte ratios and body weight. Av. Dis., 30:345 346.

Harms, R.H.; M.A. Motl and G.B. Russell (2000). Influence of age at lighting dietary calcium and addition of corn oil on early egg weight from commercial layers. Journal of Applied Poultry Research, 9: 334- 342.

Hussein, M. A. A; Kout El-kloub, M.El. Moustafa; M. K. Gad El-hak and A. M. Abbas (2010). Optimal metabolizable energy and crude protein levels for Sinai laying hens. Egypt. Poult. Sci., 30 (IV): 1073-1095. 
Hemmin B. and Rajak C. (2006). $\mathrm{CoQ}_{10}$ : absorption, tissue up-take, metabolism and pharmacokinetics. Free Radic. Res. 40(5), 445-453.

Hetland, H.; B. Svihus and M. Choct (2005). Role of insoluble fiber on gizzard activity in layers. Worlds Poultry Science J., 60: 415-422.

Kikusato, M.; K. Nakamura; Y. Mikami; A. Mujahid and M. Toyomizu(2015). The suppressive effect of dietary coenzyme Q10 on mitochondrial reactive oxygen species production and oxidative stress in chickens exposed to heat stress. Animal Science Journal doi: 10.1111/asj.12543

Kirby, J.D., M.V. Mankar; D. Hardesty and D.L. Kreider (1996). Effects of transient prepubertal hypothyroidism on testis development and function in the domestic fowl. Biology Reproduction, 55, 910-916. http://dx.doi.org/10.1095/biolreprod55.4.910

Lippense, M.; G. Huy ghbaert and G. Degroote (2002). The efficiency of nitrogen retention during compensatory growth of food-restricted broilers. British Poultry Science Journal, 43: 669- 676.

Mateos , G.G.; E. Jiménez-Moreno; M.B. Serrano and R.B. Lázaro ( 2012). Poultry response to high levels of dietary fiber sources varying in physical and chemical characteristics. J. appl. Poult. Res. $21: 156-174$.

Nering, S.; R.Vita; J. Aloyzas; Z. Henrikas and A. Magnus (2009). Assessment of sperm quality traits in relation to fertility in boar semen. Acta Veterinaria Scandinavica, 51, 1.

Niki, E.; N. Noguchi and N. Gotoh (1993). Dynamics of lipids peroxidation and its inhibition by antioxidants. Biochemical Societ. Transctions, 21: 313-317.

NRC (1994). National Research Council. Nutrient Requirement for Poultry. Ninth Revised Ed. National Academy Press, USA. Perez, V. G.; C. M. Jacobs; J. Barnes; M. C. Jenkins; M. S. Kuhlenschmidt; G. C.

Peters, S.O.; E.A. Omidiji; C.O.N. Ikeobi; M.O. Ozoje and O.A. Adebambo (2004). Effect of naked neck and friz- zled genes on egg traits, fertility and hatchability in local chicken. Self Sufficiency of Animal Protein in Nigeria. Proceedings of the 9th Annual conference of Anim. Sci. Assoc. Nig., Ebonyi State University, Abakaliki, 262-264.

Riddell, C. (1987). Avian Histology. By American Association of Avian pathology. INC. A- 11. Rights reseved.

Ravie, O. and P.E. Lake (1985). The phospholipid-bound fatty acids of fowl and turkey spermatozoa. Animal Repro.Sci. 9: 189-192.

Ritchie, B. W.; J. G. Harrison, and R. L. Harrison (1994). Avian Medicine. Winger's Publishing Inc, Florida, USA, pp. 176-198. 
Romero-Sanchez, H., Plumstead, P.W., Leksrisompong, N., Brannan, K.E. and Brake, J. (2008). Feeding Broiler Breeder males. 4. Deficient feed allocation reduces fertility and broiler progeny body weight. Poultry Science, 87, 805-811. http://dx.doi.org/10.3382/ps.2007-00285

Sarah, M. (2001). Selecting males by sperm quality. World Poultry-Elsevier, 17, 32-34.

Snedecor, G.W. and Cochran, W.G. (1982). Statistical Method. 7th Edition, Iawa State University Press, Ames, 325-330.

SPSS. (2008). SPSS User's Guide Statistics. Ver. 17. Copyright SPSS Inc., USA.

Surai, P. F.; E. Kutz; G.J. Wishart, G. J; R.C. Noble and B.K. Speake (1997). The relationship between the dietary provision of $\alpha$-tocopherol and the concentration of this vitamin in the semen of chicken: effects on lipid composition and susceptibility to peroxidation. Journal of Reproduction and Fertility, 110: 47-51.

Upendra, H.A.; S.K. Mitra and T. Suryanayana (2000). Effect of speman vet powder on semen quality and hatchability in poultry. Veterinarian, 24, 23.

Yokoyama H.; D.M. Lingle; J.A. Crestanello; J. Kamelgard; B.R. Kott; R. Momeni J. Millili; S.A. Mortensen and G.J. Whitman (1996). $\mathrm{CoQ}_{10}$ protects coronary endothelial function from ischemia reperfusion injury via an antioxidant effect. Surgery. 120 (2): 189-196.

\section{تـاثير إضافة الإنزيم المساعد كيو • 1 الصناعي أو الطبيعي من زيت الإني

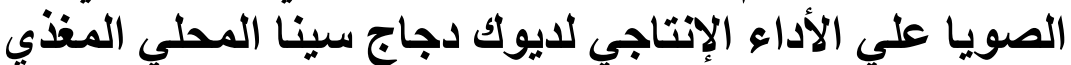 علي عليقة منخفضة في الطاقة}

ملاك منصور بشاره ، هاني نبيل فهيم، ياسر صديق رزق ، هشام محمود محمد عزوز، عرفات عبد الهادي حبئي

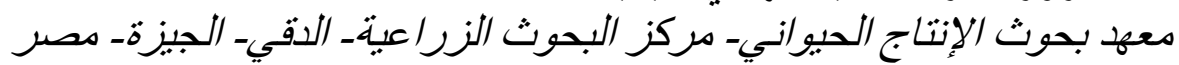

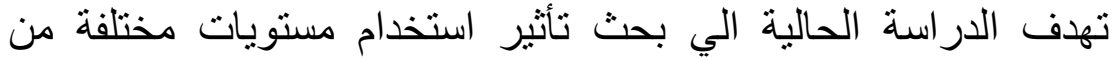

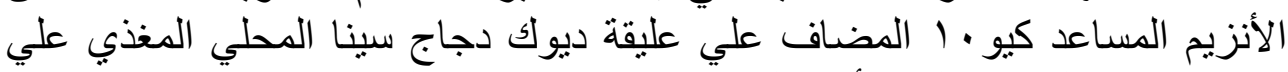

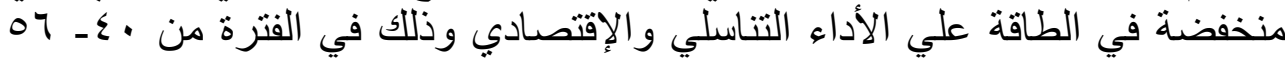

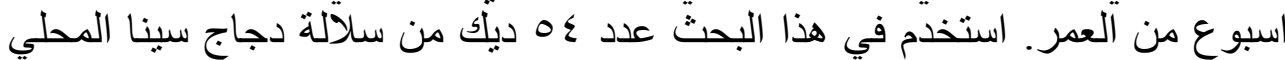
عند عمر •ـ اسبوع تم وزن الطيور وتقسيمها الي ستة مجاميع تجريبية في ثلاثة

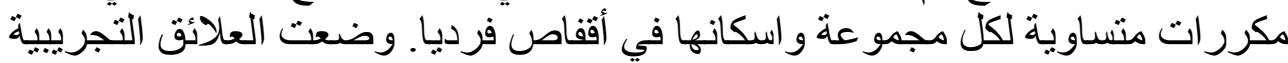




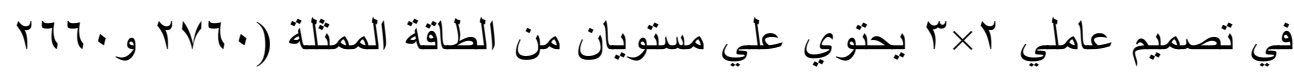

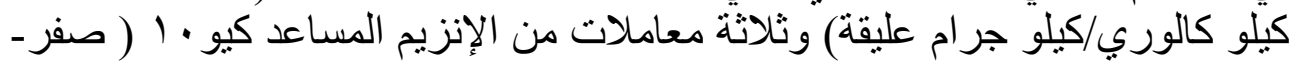

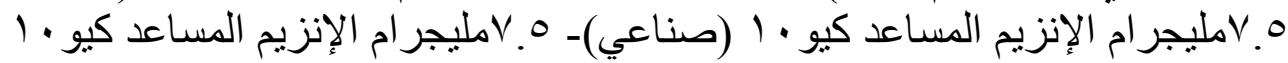

$$
\begin{aligned}
& \text { (طبيعي). } \\
& \text { وفيما يلي أهم النتائج المتحصل عليها: }
\end{aligned}
$$

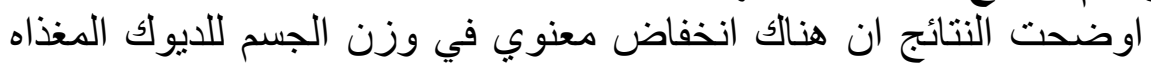

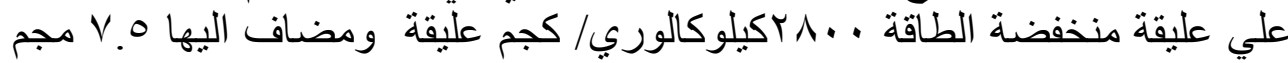

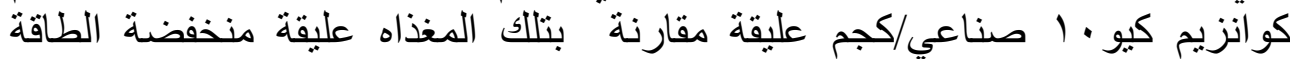

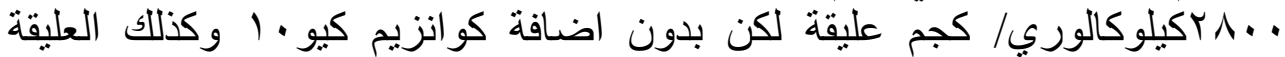

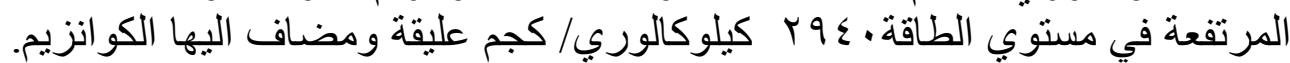

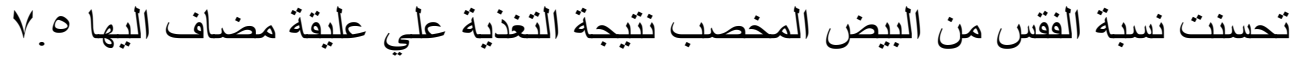

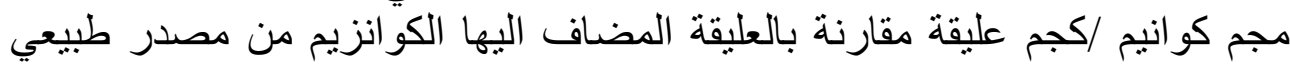

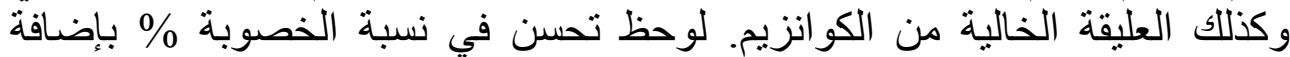

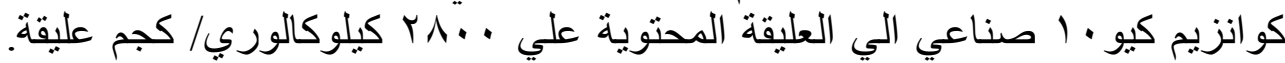

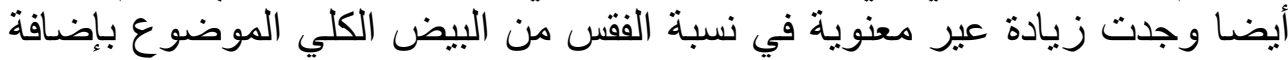

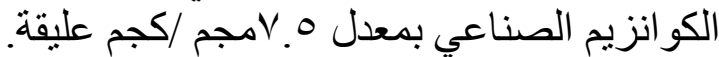

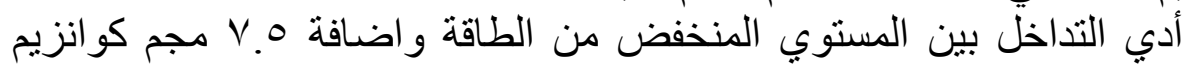

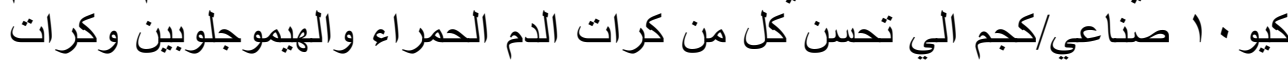

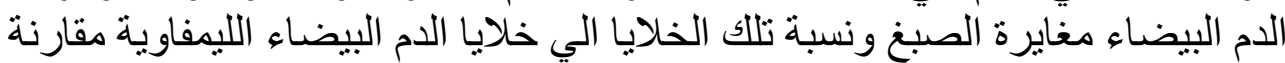
بمعاملات التداخل الاخري. لوحظ تحسن معنوي في كل من من الحركة التقدمية للإسبرمات \% و مستوي جليسريدات سيرم الدم بخفض مستوي طاقي لئة عليقة الديوك.

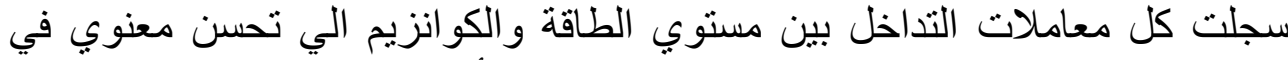

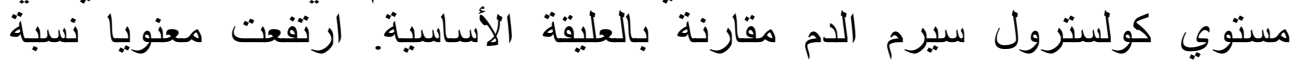

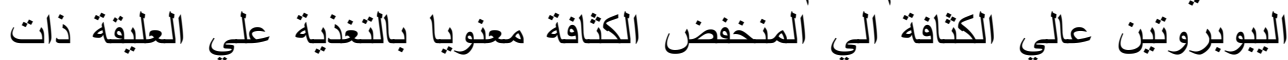

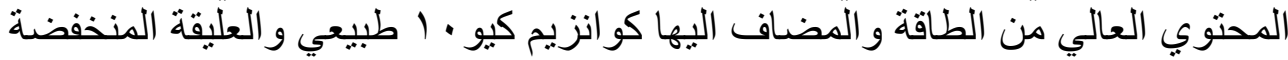

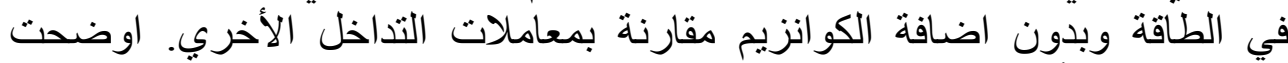

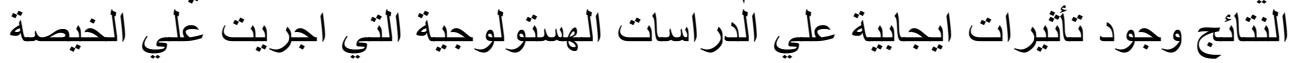

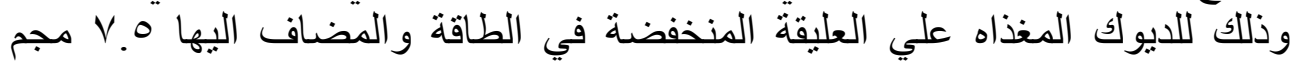

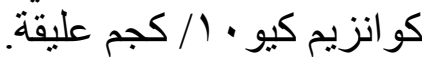

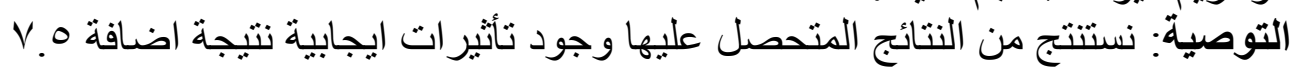

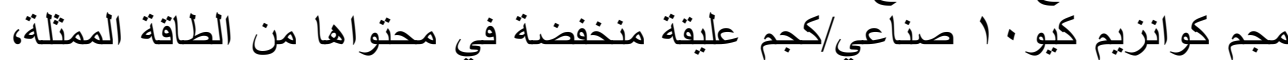

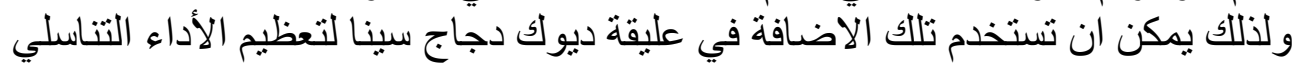

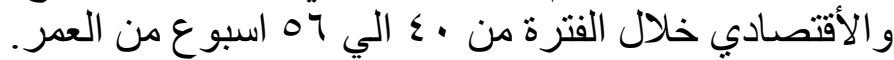

